\title{
THE EFFECT OF THE TRUST RECEIPTS ACT
}

\author{
George Gueason Bogert*
}

7 HE adoption of the Uniform Trust Receipts Act by New York ${ }^{\mathbf{x}}$ in I934 and by Illinois, ${ }^{2}$ Indiana, ${ }^{3}$ and Oregon ${ }^{4}$ in r 935 makes

1 pertinent a discussion of the effect of this statute on the law of lender and borrower and sales financing.

The act was prepared for the National Conference of Commissioners on Uniform State Laws by Professor Karl N. Llewellyn of the Columbia University Law School during the years 1925 to I933. Its growth can be traced and its theories discovered by an examination of the annual handbooks of the Conference during that period. 5

That the statute is difficult to understand is shown by the memorandum of Governor Horner of Mlinois which he filed with the Secretary of State when he permitted the bill to become law last July without his signature. The Governor said:

This law .... is a very complicated and technical act, the purposes of which are not readily discernible. It consists of a number of innovations to our credit system affecting the manner of operation of conditional sales, trust receipt contracts and warehouse receipts as pledges to secure credits. In view of the complicated nature of the Bill and the short time I have at my disposal for the consideration of the same, I am impelled to rely upon the legislative judgment, and I am therefore constrained to file the same without my signature.

The commercial practice, law and theory relating to trust receipts prior to the Uniform Act have been discussed in many texts and law review articles. $^{6}$

* Professor of Law, University of Chicago Law School.

I Laws 1934, c. 574, now Personal Property Law, \$§ 50-58L.

${ }^{2}$ IIl. R. S. 1935, c. 140a, $\$ \S 13-34$, in effect July 12, 1935. The Illinois Act differs from the Uniform Act as approved by the Commissioners on Uniform Laws and the American Bar Association in several material respects. These changes are noted throughout this article.

3 Ind. Laws 1935 , c. $206 . \quad 1$ Ore. Laws $x 935$, c. 224.

5 Handbook Nat. Conf. Com'rs on Uniform State Laws (r925), p. 594; id. (r926), 399; id. (1927), p. 607; id. (1928), p. 35; id. (1929), p. 205; id. (1930), p. 267; id. (1931), p. 296; id. (1932), p. 205; id. (1933), p. 24 r.

- For discussions of the common law and early history of trust receipts, see Frederick, The Trust Receipt as Security, 22 Col. L. Rev. 395, 546 (I922); Taylor, Trust Receipts, 6 Cornell L. Q. 168 (I92 I); Hanna, Trust Receipts, 29 Col. L. Rev. 545 (r929), rg Calif. L. Rev. 257 (I929); Vold, Trust Receipt Security in Financing of Sales, $1_{5}$ Cornell L. Q. 543 (I930); I Williston, Sales, $88338 a-338 b, 437$ (2d ed. r924); Bogert, Commentaries on Conditional Sales 
No attempt is here made to treat the minute details of the Act. The effort is rather to give a broad, general view of its purposes. It may perhaps be most profitably studied and compared with the common law under the following heads:

I. What is a trust receipt transaction?

III. Its validity against creditors.

III. Its validity against purchasers.

IV. Filing provisions.

V. Enforcement of the trust receipt.

VI. Pledges affected by the act.

VII. Summary.

I. WHAT IS A TRUST RECEIPT TRANSACTION UNDER THE ACT?

\section{A. Types of property covered by a trust receipt}

The property covered by a trust receipt transaction under the Act must belong to one or more of the following three classes, namely:7

(I) "Goods" (e.g., machinery, grain).

(2) "Documents" (e.g., bills of lading or warehouse receipts representing goods).

(3) "Instruments" (e.g., bonds, stock certificates, notes).

\section{B. Parties to trust receipt must be lender and borrower}

The two necessary parties to the trust receipt transaction (called in the act "entruster" and "trustee") must occupy the relation of lender and borrower toward each other. The word "trustee" is used in the act in an artificial sense, ${ }^{8}$ and does not connote a true equity trustee. ${ }^{9}$ The trust receipt does not involve a strict trust or other fiduciary relation. ${ }^{\text {Io }}$

C. What lenders and borrowers may be parties to a trust receipt?

But it is only particular lenders and borrowers who may be parties to the trust receipt transaction. The lender must fall into one of the following classes: ${ }^{\text {II }}$

$\S$ I 2 (I924). Student notes on the Uniform Trust Receipts Act are found in 4 Brooklyn L. Rev. I00 (I934); 4 Fordham L. Rev. I08 (I935); 9 St. Johns L. Rev. 250 (I934); 82 U. Pa. L. Rev. 270 (r934); 20 Va. L. Rev. 689 (1934).

7 Uniform Act, $\S \S \mathrm{I}, 2$; Illinois Act, $\$ \S \mathrm{I} 3, \mathrm{I4}$.

8 Uniform Act, $\S$ I (I4); Illinois Act, $\$ I_{3}$ (I4).

9 As to the distinctions between a strict trust and a trust receipt see Bogert, Trusts and Trustees $\$ 3^{8}$ (I935).

so Davis v. Aetna Acceptance Co., 293 U.S. 328 (1934), noted in 2 Univ. Chi. L. Rev. 475 (I935).

II Uniform Act, § 2; Illinois Act, § 14 . 
(I) An old creditor who delivers to his debtor as "trustee" goods, documents or instruments in which he (the old creditor) already has a security interest; wipes out the old security interest and takes in place thereof a trust receipt security interest in the same subject matter.

Illustration.-A is in possession of jewelry as a pledgee from $B$ to secure a loan previously made from $A$ to $B$. A releases $B$ from the pledge, delivers the jewelry to $B$, and in place of the pledge takes from $B$ a trust receipt on the jewelry. The transaction is a valid trust receipt transaction under the act. ${ }^{22}$

(2) A new ${ }^{13}$ creditor who delivers goods, documents, or instruments to his borrower in return for a security interest therein under a trust receipt.

Illustration.- Hides are sold by A in the Argentine to B in Chicago, the bill of lading for them being made out to $C$ (a Chicago bank) which has issued a letter of credit for $B$ in favor of $A$ and paid drafts drawn by $A$ on $\mathrm{C}$ for the price of the hides. $\mathrm{C}$ delivers the bill of lading to $\mathrm{B}$ in order that $B$ may sell the hides and get money to pay $C$, and $C$ takes a trust receipt on the hides from $B$. The transaction is a valid trust receipt transaction under the act.

(3) A new creditor contracts for a security interest by way of trust receipt in documents or instruments exhibited by the borrower to the lender at the place of business of either, before the transaction is completed, but possession of the documents or instruments is retained by the borrower.

Illustration.-A (a banker) lends money to $\mathrm{B}$ on the understanding that he (A) is to have a trust receipt security interest in a share of stock belonging to $B$ as general owner, the stock certificate for which is shown by $B$ to $A$ in the $A$ bank before the loan but is thereafter left with $B$ for one of the purposes hereafter described. The transaction is a valid trust receipt transaction under the act.

(4) A new creditor lends money in reliance on getting a security interest by way of trust receipt in goods or documents then in the possession of the borrower. ${ }^{\mathrm{I}}$

Illustration.-The A bank lends B money in reliance on getting a trust receipt security interest in automobiles then in B's possession and gen-

I2 Uniform Act, $\$$ I 4 (Illinois Act, $\$ 26$ ) provides: "As against purchasers and creditors, the entruster's security interest may extend to any obligation for which the goods, documents or instruments were security before the trust receipt transaction, and to any new value given or agreed to be given as a part of such transaction; but not, otherwise, to secure past indebtedness of the trustee; nor shall the obligation secured under any trust receipt transaction extend to obligations of the trustee to be subsequently created."

${ }_{23}$ The Tllinois Act includes renewals and extensions of time as giving "new value," although the Uniform Act does not. Illinois Act, $\$$ I3 $_{3}(7)$; Uniform Act, $\$ I(7)$.

${ }^{4}$ This provision is peculiar to the Tllinois Act. 
erally owned by B, and the bank leaves the automobiles in B's possession for one of the authorized purposes later defined. The transaction is a valid trust receipt transaction under the act.

The act thus permits the security interest under the trust receipt to come to the lender in either of the following ways:

(a) In substitution for an existing security interest which he has; or

(b) From a third party (like the seller of goods to the borrower); or

(c) Direct from the borrower.

The statute requires the lender's acts to be performed in return for a written trust receipt or a promise to give a written trust receipt..5

The debt to be secured by the trust receipt may be a new debt or some types of old debts, but not a future debt. ${ }^{26}$

The lender ("entruster") under a trust receipt within the act cannot be one who, at the beginning of the transaction, was a general owner of, and dealer in, the goods or instruments, and who sells them to the borrower ("trustee") on credit, and retains security by way of conditional sale or chattel mortgage. ${ }^{17}$ The act is intended to be without effect on the preexisting law of conditional sales and chattel mortgages. Nor may the lender under the act be a consignor of goods who places them with a consignee for sale as agent. ${ }^{18}$ The law of consignor and consignee is not intended to be affected by the act.

These rules as to the required character of the lender and borrower extend the trust receipt to some new cases which had not generally been held to be covered by that phrase at common law, namely, cases (I) and (3) above. The typical trust receipt case at common law was case (2) above. As to case (4) there was doubt, some courts ${ }^{19}$ requiring the security title to pass to the lender from a third party, not the borrower; that is, requiring the trust receipt transaction to be a three party transaction, normally that of seller, buyer and bank financing the buyer. The act extends the use of the trust receipt to many two party transactions.

\section{Requirements as to possession of goods, documents or instruments}

As shown above, under the $\operatorname{act}^{20}$ a trust receipt transaction cannot exist without possession of the goods, documents, or instruments which are to be its subject matter either

xs Uniform Act, $\S_{2}(\mathrm{I})(\mathrm{b})(\mathrm{I})$ and (II); Illinois Act, $\S \mathrm{I}_{4}(\mathrm{r})(\mathrm{b})(\mathrm{I})$ and (II).

${ }^{6}$ Uniform Act, \& $\mathrm{I} 4$; Tllinois Act, \& 26 . .

${ }_{77}$ Uniform Act, $\S \mathrm{I}(3)$; nlinois Act, $8 \mathrm{r}_{3}(3)$.

${ }^{88}$ Uniform Act, 8 I5; Illinois Act, $\$ 27$.

19 See, for example, In re A. E. Fountain Co., Inc., 282 Fed. 816 (C.C.A. 2d I922); Hartford Accident \& Indemnity Co. v. Callahan, 27 I Mass. 556, I7I N.E. 820 (r930).

30 Uniform Act, §2; Illinois Act, § $\mathrm{r}_{4}$. 
(I) Remaining in the borrower as a result of the transaction; or

(2) Passing to the borrower as a result of the transaction.

E. Requirements as to purpose for which possession is retained or obtained by borrower

Not only must the lender and borrower be of a particular type, and not only must the lender permit the borrower to retain or get possession, but that possession must be kept or obtained for one or more of a limited number of purposes, if the transaction is to be a trust receipt transaction under the act. ${ }^{2 x}$ The purpose must be one of the following:

(I) In order to enable the borrower to sell or exchange goods, documents or instruments entrusted.

Illustration.-A finance company permits B to get possession of automobiles and put them in his show room for sale, the company taking a trust receipt on the automobiles. The purpose is proper.

(2) In order to enable the borrower to process or handle the goods entrusted, or the goods represented by the document entrusted, preparatory to sale by the borrower.

Illustration.-A bank, having advanced the price of hides, on behalf of a buyer, delivers to him the bill of lading for the goods in order that he may have the hides tanned and sold; and the bank takes a trust receipt on the hides. The purpose is proper.

(3) In order that instruments delivered to, or retained by, the borrower may be (a) delivered to a principal of the borrower; or (b) delivered to a depositary or registrar; or (c) used for presentation, collection or renewal.

Illustration.- A bank lending money to $B$ has exhibited to it at the bank a note owned by $B$, and lends in reliance thereon to $B$, getting from $B$ a trust receipt security interest in the note. It permits $B$ to keep the note in order that he may collect it from the maker. The purpose is proper.

By section 4 of the Uniform Act $^{22}$ a contract to give a trust receipt has the same legal effect as a trust receipt with reference to goods, documents or instruments thereafter delivered to the borrower in reliance on such contract, or (under the Illinois Act) with reference to goods, documents or instruments in the hands of the borrower and which are the source of a security interest given in return for new value. ${ }^{23}$

2x Uniform Act, § 2(3); Tlinois Act, § I4(3).

22 Uniform Act, $\S \mathrm{I} 6$; Illinois Act, $\S \mathrm{r} 6$.

${ }^{23}$ This last clause is peculiar to the Illinois Act, $\S \mathrm{I} 6$. 


\section{VALIDITY OF A TRUST RECEIPT AGAINST CREDITORS OF THE BORROWER}

As between borrower and lender all terms of the trust receipt are valid, except that a waiver by the borrower of his equities under the receipt is invalid, ${ }^{24}$ on analogy to the rules with regard to the clauses in mortgages waiving the equity of redemption ${ }^{25}$ and in conditional sales waiving statutory protection of equities. ${ }^{26}$

The fundamental purpose of the trust receipt is to afford lenders short term protection against the honest insolvency of their borrowers. It was, therefore, accepted at common law that the trust receipt was valid against the creditors of the borrower, whether lien or general, and whether acting for themselves or through a representative like a trustee in bankruptcy. ${ }^{27}$

\section{A. Validity against creditors continued in qualified manner}

The act continues this validity against creditors of the borrower in large part, but somewhat qualifies it. ${ }^{28}$ The lender is protected in his security interest in the subject matter against the creditors of the borrower to the following extent:

(I) For thirty days without filing.

(2) After thirty days the trust receipt is invalid against lien creditors of the borrower who have acquired a lien on the goods without actual notice of the trust receipt, if (a) the trust receipt was not filed, or $(b)$ the lender had not taken possession of the subject matter before the acquisition of the lien by the creditor.

(3) The borrower's assignee for creditors, receiver or trustee in bankruptcy is a lien creditor without notice under the act if any of the creditors whom he represents did not have notice of the trust receipt before the representative of creditors was appointed. ${ }^{29}$

(4) Filing (as later described) makes the trust receipt valid against all creditors of the borrower from the time of filing.

24 Uniform Act, $\$ 5$; Tlinois Act, $\$ 17$.

${ }_{25}$ See 2 Jones, Mortgages $\$ 1326$ (8th ed. 1928).

${ }^{26}$ See Bogert, Commentaries on Conditional Sales $\S \S \mathrm{r} 35^{-142}$ (I924).

${ }^{27}$ Century Throwing Co. v. Muller, I97 Fed. 252 (C.C.A. 3 d I912); In re Bell Motor Co., 45 F. (2d) I9 (C.C.A. 8th I930); Houck v. General Motors Acceptance Corp., 44 F. (2d) 4 ro (D.C. Pa. r930); In re James, Inc., 30 F. (2d) 555 (C.C.A. 2d r929); Peoples' National Bank v. Mulholland, 224 Mass. 448 , Ir3 N.E. 365 (I9I6); $i b .228$ Mass. I52, II7 N.E. 46 (IgI7).

28 Uniform Act, §8; Tllinois Act, \$20.

29 The Illinois Act omits a provision of the Uniform Act, $\S 8(2)(a)$, making a creditor who procures the issuance of process a lien creditor, from the time of issuance, if he attaches or levies within a reasonable time thereafter. (Illinois Act; $\S 8(2)$.) 
(5) Taking possession ${ }^{30}$ of the subject matter by the lender makes the trust receipt valid against all creditors of the borrower from that time forth.

(6) Creditors of the borrower who acquired their claims by processing, transporting or warehousing the goods held under the trust receipt, and get liens thereby, are superior to the lender to the extent of their liens, regardless of filing. ${ }^{3 x}$

Illustration.-A bank entrusts cotton to a borrower in order to have it ginned and sold. The borrower has it ginned and warehoused and the state law gives ginners and warehousemen liens. These liens are superior to the trust receipt security rights of the bank, even though the bank had previously filed in accordance with the act.

\section{VALIDITY OF THE TRUST RECEIPT AGAINST PURCEASERS FROM BORROWER}

Since a cardinal object of the trust receipt transaction is ordinarily to enable the borrower to sell the goods in order to raise money to pay the lender, it has been generally held at common law that the lender could not assert any rights against the purchaser from the borrower in the usual case. $^{32}$ The lender has given an express or implied power of sale by which he should be bound.

The act in general continues this protection of the purchaser and also provides rules regarding other types of transfer. ${ }^{33}$ The situation under the act may be indicated by the following outline:

\section{A. Negotiable documents and instruments}

(I) If the borrower negotiates a negotiable document or instrument to a bona fide purchaser or holder in due course the latter acquires good title against the lender. ${ }^{34}$

${ }^{30}$ Uniform Act, $\S \mathrm{I}(9)$, Illinois Act, $\S \mathrm{I}_{3}(9)$ provides: "'Possession,' as used in this Act with reference to possession taken or retained by the entruster, means actual possession of goods, documents or instruments, or in the case of goods, such constructive possession as, by means of tags or signs or other outward marks placed and remaining in conspicuous places, may reasonably be expected in fact to indicate to the third party in question that the entruster has control over or interest in the goods."

${ }^{3} \S$ Ix. For a contrary view at common law, see Century Throwing Co. v. Muller, I97 Fed. 252 (C.C.A. 3 d I9I2).

${ }^{32}$ Glass v. Continental Guar. Corp., 8I Fla. 687 , 88 So. 876 (r92r); Handy v. C.I.T. Corp., I97 N.E. 64 (Mass. I935).

33 Uniform Act, § 9; Illinois Act, § 2I.

${ }^{34}$ It was so held in Roland M. Baker Co. v. Brown, 214 Mass. Ig6, roo N.E. 1025 (Igr3), with regard to negotiable bills of lading; and in Commercial National Bank of New Orleans v. Canal-Louisiana Bank \& Trust Co., 239 U.S. 520 (rgr6), and in In re Richheimer, 22I Fed. 16 (C.C.A. 7 th I915), with regard to negotiable warehouse receipts. 
(2) Filing under the act is not constructive notice to a purchaser of a negotiable document or instrument.

(3) The entrusting of a document or instrument includes the case of a document or instrument substituted for the one originally entrusted, and a document or instrument representing the same goods as those represented by the document originally entrusted. ${ }^{35}$

\section{B. Non-negotiable instruments and documents; and goods}

(I) A purchaser in the ordinary course of business from the borrower gets title free of the trust receipt, if the borrower had an unlimited power of sale, regardless of filing.

Illustration.-A finance company entrusting automobiles to a dealer for sale under a trust receipt files the notice later described under the act, and thereafter $\mathrm{B}$, as a regular customer of the dealer, purchases an automobile from the dealer either with or without knowledge of the filing and relationship between the company and the dealer. $B$ gets perfect title.

(2) A purchaser in the ordinary course of business from the borrower gets title free of the trust receipt, even though the sale was in violation of the limitations on the borrower's authority to sell, unless the purchaser had actual knowledge of such limitations. ${ }^{36}$

Illustration.-Same as last illustration, except that the dealer is authorized to sell for cash only. The filing does not bind B and unless he had actual knowledge of the limitation on the dealer's power of sale, he gets perfect title, even though he bought on credit.

(3) A purchaser out of the ordinary course of business (including a chattel mortgagee, ${ }^{37}$ a pledgee, ${ }^{38}$ and a buyer in bulk from the borrower) takes subject to the trust receipt regardless of filing or its lack, except (a) where a pledgee or mortgagee gives new value to the lender as mort-

35 This follows the view of the Supreme Court in Commercial National Bank of New Orleans v. Canal-Louisiana Bank \& Trust Co., 239 U.S. 520 (rgr6), and the opinion in In re Richheimer, $22 \mathrm{r}$ Fed. r6 (C.C.A. 7 th 1915).

${ }^{36}$ In accord with this provision, see Handy v. C.I.T. Corp., I97 N.E. 64 (Mass. I935), where an automobile was put into the hands of a dealer to sell but no sale was to occur without written consent of the finance company, and it was held that a bona fide purchaser in the ordinary course from the dealer without the written consent of the finance company was protected.

${ }^{37}$ In Peoples' Loan \& Inv. Co. v. Universal Credit Co., 75 F. (2d) 545 (C.C.A. 8th 1935), it was held that a trust receipt was valid against the taker of a second trust receipt from the borrower in possession, the latter transaction being in all probability equivalent to an attempted chattel mortgage.

${ }^{38}$ This is contrary in effect to International Trust Co. v. Webster National Bank, 258 Mass. I7, I54 N.E. 330 (rg26), and Osgood Bradley Co. v. Standard Co., 259 Mass. 302 , I 56 N.E. 440 (I927), where bona fide pledgees from the borrower in possession were protected against the trust receipt on the ground that the borrower was a "factor" under the Massachusetts Factor's Act. 
gagor or pledgor within thirty days after the giving of the trust receipt and gets possession of the goods, documents or instruments before the filing of the trust receipt, or (b) the pledgee, mortgagee or buyer in bulk gives value after the thirty day period and gets possession before the trust receipt filing.

(4) Putting or keeping goods in a stock or show room of the lender, or permitting such conduct, has the legal effect of conferring a power of sale on him.

(5) A purchaser on credit from the borrower is a purchaser for value.

IV. FILING UNDER THE ACT

Filing of the trust receipt under the act is accomplished not by filing an individual trust receipt or copy thereof, but by filing with the Secretary of State a statement signed by lender and borrower, giving their addresses, to the effect that they intend to do business on the trust receipt plan with regard to a particular type of goods. The validity of the filing continues for one year, when refiling is permitted. Filing is allowed only as to trust receipts dealing with goods and documents and not as to transactions with regard to instruments. ${ }^{39}$

Prior to the act in most jurisdictions there was no provision for filing a trust receipt and it was valid without filing or recording. Occasionally, however, the trust receipt was regarded as equivalent to a conditional sale $^{40}$ or a chattel mortgage ${ }^{4 x}$ and required to conform to the filing or recording statutes applying to those transactions. In Illinois a federal decision ${ }^{42}$ construed a trust receipt to be equivalent to a conditional sale and so at that time invalid except between the parties and against third parties with notice. Since the validation of conditional sales in Mllinois in I925 by the construction of the Uniform Sales Act in the Sherer-Gillet case, ${ }^{43}$ the conditional sale has been good against all persons (before default) without recording ${ }^{44}$ or filing, and the trust receipt has presumably been valid as one type of conditional sale; but the Uniform Trust Receipts

39 Uniform Act, § r3; Tllinois Act, § 25 .

$4^{\circ}$ In re Bettman-Johnson Co., 250 Fed. 657 (C.C.A. 6th I9r8); Ohio Sav. Bank \& Trust Co. v. Schneider, 202 Ia. 938, 2 II N.W. 248 (I926); White v. General Motors Acceptance Corp., 2 F. Supp. 406 (D.C. Ky. I932).

4 Motor Bankers' Corp. v. C.I.T. Corp., $25^{8}$ Mich. 302, 24r N.W. grI (I932).

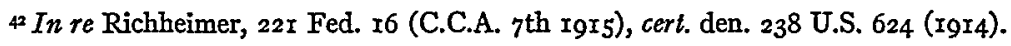

43 Sherer-Gillet Co. v. Long, 3 I 8 IIl. 432, 449 N.E. 225 (I925).

44 The lack of a recording or filing statute in tllinois as to conditional sales may permit a lender to get security without any publicity. He can take a bill of sale from his borrower and give back to the borrower a conditional sales contract. Will lenders in Illinois from now on resort 
Act has changed this situation by treating the trust receipt transaction as an independent dealing, distinct from the conditional sale.

In Ohio a statute of 1925 permitted filing of notices ${ }^{45}$ with regard to trust receipts of "readily marketable staples." A recent Connecticut statute also deals with the same matter..$^{6}$

\section{ENFORCEMENT OF TRUST RECEIPTS UNDER TETE ACT}

A. Taking possession of goods, documents or instruments; sale

If the borrower defaults in paying the lender the amount loaned, for which the trust receipt is security, the lender may take possession of the subject-matter of the trust receipt and sell it on five days notice, the proceeds to be applied on the debt and expenses, any surplus to go to the borrower and any deficiency to be paid by the borrower. ${ }^{47}$

The lender having taken possession need not sell, but may keep the goods and then be subject to the duties of a pledgee regarding them.

In the case of goods manufactured by style or model the lender may provide in the trust receipt for a right to apply the value of the goods retaken against the borrower's debt without a sale.

The borrower may, after default, surrender his interest in the goods to the lender, but may not contract in the trust receipt for a waiver or forfeiture of his equities.

A bona fide purchaser from the lender in possession gets good title, even though the possession by the lender may have been wrongful.

B. Proceeds of goods, documents or instruments in hands of borrower or others

(I) If the subject matter of the trust receipt has been sold by the borrower under a power of sale, and the borrower defaults, the lender is entitled to the debt from the purchaser to the borrower plus any security given as an incident thereto, subject to any equities in favor of the purchaser and against the borrower which accrued before the purchaser had actual notice of the trust receipt.

Illustration.-A bank has put a borrower into possession of goods to sell. The borrower sells them to $\mathrm{X}$, taking a note of $\mathrm{X}$ for the price and a chattel mortgage by $\mathrm{X}$ on other goods. The borrower defaults in his duty

to the secret, rather roundabout security of the conditional sale in order to avoid possible filing and foreclosure complications under the Uniform Trust Receipts Act? The need for the adoption in Illinois of a conditional sales filing statute is increasingly apparent.

4s Laws I925, p. rr6.

- ${ }^{6}$ Conn. Laws 1935 , c. 230 , Gen. Stat. $\$$ r 574 c.

47 Recovery of a deficiency after retaking and sale by the lender was approved in Charavay \& Bodvin v. York Silk Mfg. Co., ryo Fed. 8rg (C.C. N.Y. rgog). 
to pay the bank. The bank may take the note of $\mathrm{X}$ and the chattel mortgage in order to protect itself under the trust receipt.

(2) If the subject matter was sold by the borrower when there was no power of sale, the lender is entitled, if the borrower defaults, to the debt against the purchaser and to the proceeds of the subject matter received by the borrower (or the value of such proceeds), if they were received by him within ten days of his receivership or bankruptcy.

Illustration.-Same as case next above, except that borrower had no power of sale and took as payment cash, and went into bankruptcy within ten days. The lender is entitled to a preference out of the bankrupt estate to the amount of the cash thus received.

(3) If the subject matter was sold under a power of sale in the borrower, where there was a duty to account to the lender for the proceeds of such sale, ${ }^{48}$ the lender is entitled, if the borrower defaults in his obligations, to the debt from the buyer of the goods and to the proceeds ${ }^{49}$ of the goods (or the value of the proceeds), if received by the borrower within ten days of receivership or bankruptcy.

These provisions grant preferred claims to the lender under the trust receipt. He does not have to trace or identify proceeds. The principles of following trust funds, applied in the law of trusts, ${ }^{50}$ are ignored. The statute is extremely liberal to the lender under the trust receipt in his contest with the general creditors of the borrower. ${ }^{5 x}$

\section{EFFECT OF STATUTE ON PLEDGE LAW}

The Trust Receipts Act also covers some types of pledge transactions, not on the theory that they may properly be called trust receipt dealings, but on the notion that, although not trust receipt cases, they are so nearly like the trust receipt device that they ought to be governed in the same act and by similar rules.

\section{A. Pledge without delivery}

The act first covers the case of an attempted pledge without delivery of the res to the pledgee. This transaction at common law would normally

$4^{8} \mathrm{~A}$ provision in the Uniform Act, $\S \mathrm{IO}(\mathrm{c})$ regarding waiver of a right to an accounting has been omitted from the Mlinois Act. $\S$ ro(c).

49 In Hamilton National Bank v. McCallum, 58 F. (2d) 9r2 (C.C.A. 6th r932) it was held under Tennessee law that the holder of the trust receipt was the owner of the proceeds of goods sold by a bankrupt lender, as against his trustee in bankruptcy.

${ }^{\text {so }}$ See Bogert, Trusts \& Trustees $\$ \$ 92 \mathrm{r}-930$ (I935).

sn Illinois Act, $\S 30$, making misappropriation of the proceeds of goods by the borrower a felony, is not found in the Uniform Act. 
be ineffective as a pledge because of the rule that possession in the pledgee is a prerequisite to the perfection of a pledge transaction..$^{22}$ The statute provides that such an attempted pledge without transfer of possession shall be valid in favor of a pledgee who gives new value, for ten days, against the pledgor's creditors; but invalid in favor of such a pledgee, after ten days, against lien creditors of the pledgor without notice. Such a so-called pledge is also invalid when in favor of a pledgee who took the pledge for an old debt and did not give new value, as against lien creditors without notice; and also invalid against bona fide purchasers from the pledgee. This gives, therefore, a very limited vitality to a pledge without any transfer of possession to the pledgee.

\section{B. Redelivery of pledge to pledgor for temporary use}

The act, secondly, covers the case of a pledge where the pledgee originally got possession and so the pledge had no defect, but later the pledgee delivered the goods back to the pledgor. Normally at common law it is held that such redelivery "for a temporary purpose" does not destroy the pledgee's rights against the pledgor or his creditors but does subordinate him to a bona fide purchaser under the pledgor in possession.53) The act in substance defines "temporary" to mean not more than ten days. It maintains the validity of the pledge if the redelivery is for a temporary and limited purpose, for a period of ten days, as against all creditors of the pledgor.

These provisions about pledges are, however, possibly qualified by the terms of Section I $5,{ }^{54}$ to the effect that the

Act shall not apply to single transactions of legal or equitable pledge, not constituting a course of business, whether such transactions be unaccompanied by delivery of pos-

$5^{2}$ Corbett v. Underwood, 83 IIl. 324 (I876); Atkinson v. Foster, 134 Ill. 472, 25 N.E. 528 (I8go); State v. First Nat. Bank of Jeffersonville, 89 Ind. 302 (1883); Franklin Nat. Bk. v. Whitehead, 149 Ind. 560,49 N.E. 592 ( 1898$)$; Siedenbach v. Riley, II I N.Y. 560, r9 N.E. 275 (I888); Titusville Iron Co. v. City of New York, 207 N.Y. 203, 100 N.E. 806 (IgI2); Schumann v. Bank of California Nat. Assn., Ir4 Ore. 336, 238 Pac. 860 (r925).

${ }^{3}$ Cooper v. Ray, 47 Ill. 53 (I868) (dichum); Hutton v. Arnett, 5 I Ill. I98 (I869) (dictum); Rice \& Bullen Malting Co. v. International Bank, 185 Ill. 422, 56 N.E. I062 (rgoo) (to sell goods for pledgee); Colburn v. Commercial Security Co., I 72 Ill. App. 5 ro (IgI2) (conditional sales contract delivered to pledgor to get another contract); Hollister v. Dinsmore, Igr Ill. App. 377 (Igr5) (stock delivered to pledgor for sale); Knight v. Seney, 2rr Ill. App. 324 (rgr8) (for use by pledgor as collateral temporarily); New Albany National Bank v. Brown, 63 Ind. App. 39I, II4 N.E. 486 (IgI6) (insurance policy delivered to pledgor to get assignment). See also Schumann v. Bank of California National Association, II4 Ore. 336, 233 Pac. 860 (Ig25) (redelivery destroys pledgee's rights against bona fide purchaser from pledgor in possession).

54 Illinois Act, $\$ 27$. 
session, or involved constructive delivery, or delivery and redelivery, actual or constructive, so far as such transactions involve only an entruster who is an individual natural person, and a trustee entrusted as a fiduciary with handling investments or finances of the entruster.

VII. SUMMIARY AS TO EFFECT OF ACT

A. It makes clear the meaning of the trust receipt transaction and considerably broadens the scope it had acquired in the earlier case law.

B. It establishes the fact that the trust receipt transaction is an independent, separate type of security transaction, and not merely one type of chattel mortgage or conditional sale.

C. It liberalizes the law of pledges in the direction of enabling the pledgee to get and keep his interest, notwithstanding short periods of lack of possession.

D. It provides for public notice of the existence of trust receipt relations between two parties, thus giving the credit-lending class some opportunity to guard against deceptive appearances produced by trust receipts where there has been possession by the borrower for more than thirty days.

E. It contains very liberal terms in favor of the lender as to the enforcement of his rights under the receipt, providing for an optional foreclosure sale on simple, short notice, and giving the lender important preferred creditor rights against an insolvent borrower.

F. In general the theory of the act is to give to the bank, finance company, or other lender every conceivable protection in handling trust receipt and pledge transactions, so that the use of these security devices may be increased and the financing of sales and other transactions facilitated. 